\title{
ŚWIĘTY AUGUSTYN I ZYGMUNT KRASIŃSKI - O ROMANTYCZNEJ AUTOUTOŻSAMIAJĄCEJ LEKTURZE FILOZOFA Z HIPPONY. REKONESANS
}

Słowa kluczowe: Zygmunt Krasiński, św. Augustyn z Hippony, romantyzm, czytanie utożsamiające Keywords: Zygmunt Krasiński, Saint Augustine of Hippo, romanticism, identifying reading

\section{Intrygująca nieobecność}

Zygmunt Krasiński był najbardziej „filozofującym” spośród polskich romantyków. Autor Nie-Boskiej znał myśl filozoficzną - dawną i współczesną. Lektura listów do różnych adresatów dowodzi erudycji filozoficznej poety, który obficie czerpał z dorobku wielu myślicieli, ale, co może wydawać się zaskakujące, wśród przywoływanych przez Krasińskiego nazwisk filozofów, brak właściwie odniesień do Augustyna z Hippony. Tymczasem to właśnie autor Państwa Bożego z wielu powodów wydawać się może ważnym intelektualnym sprzymierzeńcem twórcy Przedświtu. Rzymski retor powinien przyciągać uwagę romantycznego poety i autobiograficzną prawdą Wyznań, i rolą, którą spełnił w historii europejskiej cywilizacji jako fundator nowej wizji świata, nowego światopoglądu ${ }^{1}$. Pisma Augustyna będącego świadkiem rozpadu antycznego imperium ${ }^{2}$, winny poruszyć Krasińskiego - antyczny filozof wszak żył w świecie „wielkiego konania”, kulturowej dekadencji, a romantycznego poetę w sposób szczególny zajmowały momenty takiego historycznego zamętu, przesilenia, ścierania się kultur. Krasiński zresztą wielokrotnie porewolucyjną epokę, w której żył, zestawiał właśnie z obrazem upadku rzymskiego świata. Dlatego też można pytać o zdumiewająco nikłą obecność śladów lektury św. Augustyna w pismach Krasińskiego, o to, dlaczego tak niewiele odnajdujemy w nich bezpośrednich odwołań do antycznego filozofa,

${ }^{1}$ Adam Sikora, „Święty Augustyn - między piekłem a niebem”, in idem, Od Heraklita do Husserla. Spotkania z filozofia (Warszawa: Wydawnictwo Open, 2001), 94.

${ }^{2}$ Ibidem. 
choć pośrednia, inspirująca rola myśli świętego z Hippony w pismach Krasińskiego wydaje się czasem aż nadto oczywista.

W tekstach autora Państwa Bożego odnaleźć można wiele bliskich romantykom wątków. Poza filozoficzną zadumą nad dziejami stworzenia, pojawia się w nich jakże bliska romantykom, obecna w Wyznaniach i Solilokwiach, antropologia człowieka wewnętrznego i zarazem zdezintegrowanego, który może być jednocześnie najpełniejszym, najbogatszym źródłem poznania ${ }^{3}$. Dla romantyka intrygujące mogły być także dzieje Bezimiennej - nigdzie nie nazwanej z imienia miłości Augustyna, którą z rozdartym sercem, ale i z czcią i oddaniem przywoływać będzie w Wyznaniach ${ }^{4}$. Przejmująca historia uczucia, które nie mogło się dopełnić ze względu na niższą kondycję społeczną wybranki, była przecież opowieścią ze wszech miar jak ze współczesnej Krasińskiemu epoki - schemat fabularny dotyczący społecznych norm stających na przeszkodzie uczuciu powielą i Mickiewiczowskie Dziady, i wiele innych historii ${ }^{5}$. Na marginesie warto zaznaczyć, że wbrew powszechnej interpretacji (utrwalonej choćby w popularnej, opartej na motywach Wyznań powieści Vita brevis Jostein Gaarder ${ }^{6}$ ) to nie Bóg odebrał Bezimienną Augustynowi - a pragmatyzm, podporządkowanie się oczekiwaniom społecznym, którym późniejszy autor Wyznań nie potrafił się przeciwstawić ${ }^{7}$. Trudno nie pomyśleć w tym miejscu o pełnych dramatyzmu życiowych wyborach samego Krasińskiego ${ }^{8}$.

A tymczasem, mimo nielicznych bezpośrednich odwołań do pism św. Augustyna, ukrytych pulsujących $\mathrm{w}$ jego pismach inspiracji augustiańskich można

${ }^{3} \mathrm{~W}$ dialogu $O$ wierze prawdziwej Augustyn mówi: Noli fora sire, in te ipsum redi, in interiore hominis habitat veritas. Wacław Eborowicz przetłumaczył tę kwestę następująco: „Nie wychodź na świat, wróć do siebie samego, we wnętrzu człowieka mieszka prawda”. Vide Augustyn, „O wierze prawdziwej”, in św. Augustyn, Dialogi filozoficzne (Kraków: Instytut Wydawniczy „Znak”, 1999), 788.

${ }^{4}$ „Kobietę, z którą dotychczas żyłem - pisze Augustyn - oderwano od mego boku, gdyż była to przeszkoda na drodze do małżeństwa. Ponieważ moje serce mocno do niej przywarło, teraz wyszarpnięto w nim ranę, która broczyła krwią obfitą [...]". Św. Augustyn, Wyznania, trans., ed. et intr. Zygmunt Kubiak (Kraków, Instytut Wydawniczy „Znak”, 1994) księga VI, fragment 15, 134. Wszystkie cytaty z Wyznań podaję za tym przekładem, stosując w przywołaniach następujący zapis: cyfrą rzymską oznaczam numer księgi, a arabską akapit w księdze oraz dalej numer strony.

${ }^{5} \mathrm{O}$ popularności tego motywu vide Marta Piwińska, Miłość romantyczna (Kraków - Wrocław: Wydawnictwo Literackie, 1984), 526-527.

${ }^{6}$ Jostein Gaarder, Vita brevis. List Florii Emilii do Aureliusza Augustyna, trans. Iwona Zimnicka (Warszawa: Wydawnictwo Jacek Santorski \& Co, 1996). Na motywach miłości do nieznajomej powstał także monolog twórczyni krakowskiego Teatru Jednego Aktora Danuty Michałowskiej (wystawiony po raz pierwszy w 1994 roku) Ja, bez imienia (Warszawa: Biblioteka „Więzi”, 1996).

${ }^{7}$ „Trzeba też pojąć żonę dość posażną, żeby wydatki na nią zbytnio mi nie zaciążyły. I to już będzie kres moich ambicji” (VI,11,131) - filozof ironizował na temat swoich wyborów w Wyznaniach.

${ }^{8}$ Myślę tu oczywiście o ślubie poety z Elizą Branicką - podyktowanym rozsądkiem i rodowym interesem, w zgodzie z wolą ojca, a wbrew samemu Krasińskiemu uwikłanemu w uczuciowy związek z Delfiną Potocką. 
znaleźć wiele ${ }^{9}$. Dotyczą one zarówno kwestii epistemologicznych, historiozoficznych (w tym koncepcji państwa - nowoczesnej formuły Christianitas), ale przede wszystkim koncepcji egzystencjalnych.

Niewielkim, choć bardzo znaczącym, tropem stosunku Krasińskiego do Augustyna jest wzmianka poczyniona w liście poety do Adama Sołtana z 9 lipca 1846 roku. Komentując w nim śmierć księżny Marii Lubomirskiej, która „umarła prawdziwie melancholicznie"10, a z którą poeta był mocno związany (po jej śmierci kazał Sołtanowi odesłać kosmyk jej włosów), Krasiński rozważa:

Litery martwej religijnej się trzymając nie mogła doznać pociechy onej, która tylko z ducha spływa na duchy i rosą niebieską ich odwilża! Czegoś trzeba było tej duszy pragnącej, zesmętniałej, anieskończoności owej nie znalazła w formułkach, a samymi formułkami zbywano ją ${ }^{11}$.

Tym czymś, co wedle poety, dopomogłoby i „odwilżyło” spragnioną duszę księżnej, mogły stać się właśnie pisma autora Wyznań przeciwstawiane „religijnym formułkom”. „Melancholia jej byłaby prysła u stóp św. Augustyna [...]”12 - konstatował Krasiński. Poeta chciał zatem aplikować Lubomirskiej myśli Doktora Kościoła jako antidotum na melancholię, rozpacz i inne jeszcze „akwatofuny” - czyli trupie wody zalewające „czas ohydnie cierpki i niepewności pełen"13, w którym poecie, Adamowi Sołtanowi i księżnej przyszło żyć. Cenić zatem musiał autor Traktatu o Trójcy myśl Augustyna jako pisarza dającego ukojenie eschatologiczne. Pocieszenie, które miały nieść pisma Doktora Kościoła, mogło mieć dla poety wymiar szczególny. Augustyn bowiem żył, wedle rozpoznań samego poety, w czasie Krasińskiemu podobnym: przesilenia i dekadencji. Zło, i to codzienne, banalne i to wcielające się w wielką historię w postaci klęsk i upadków podobnie zaprzątało umysły obu myślicieli, obaj też na drodze intelektualnej starali się uporać z jego rozpanoszeniem w człowieku i historii, dążąc do jedności i harmonii. Obaj - intelektualiści nieco egotyczni, o wyostrzonej

${ }^{9}$ Wyczytać je można choćby w filozoficznym traktacie „O stanowisku Polski z Bożych i ludzkich względów”, gdzie zresztą Krasiński przywołuje słynny zwrot przypisywany Augustynowi o „winie szczęśliwej”. Vide Zygmunt Krasiński, Pisma filozoficzne i polityczne, ed. Paweł Hertz (Warszawa: Spółdzielnia Wydawnicza „Czytelnik”, 1999), 7; przypis wydawcy, 299.

${ }^{10}$ List z 9 VII 1846 r., in Zygmunt Krasiński, Listy do Adama Soltana, ed. Zbigniew Sudolski (Warszawa: Państwowy Instytut Wydawniczy, 1970), 500.

${ }^{11}$ Ibidem, 501.

${ }^{12}$ Ibidem. Dla porządku trzeba dodać, że obok Augustyna wymienia także Krasiński św. Hieronima, który jednak znany jest przede wszystkim jako autor przekładu na łacinę Pisma św. Wymieniając go, właściwie poeta mógł mieć chyba na myśli Wulgatę, nie sądzę, by pogrążoną w melancholii księżną chciał karmić pismami histograficznymi czy Dialogiem przeciw pelagianom. Chyba, że miał na myśli inne jeszcze pisma Hieronima z dziedziny duchowości. Warto nadmienić, że Augustyn znał Hieronima (właśc. Eusebius Hieronymus), którą to znajomość potwierdza długotrwała korespondencja o charakterze polemicznym między myślicielami. Vide Peter Brown, Augustyn z Hippony, trans. Witold Radwański (Warszawa: Państwowy Instytut Wydawniczy, 1993), 277-279.

${ }^{13}$ List z 9 VII 1846 r., in Zygmunt Krasiński, Listy do Adama Soltana, 501. 
samoświadomości, skłonni do nieustannego samooglądu - mieli przekonanie, że żyją w czasach ciekawych, ale jednocześnie przerażających. Ale właśnie nie Augustyn filozof historii, jak moglibyśmy się spodziewać, lecz Augustyn-egzystencjalista ${ }^{14}$,żarliwy acz chaotyczny poszukiwacz prawdy” poruszał Krasińskiego najbardziej. Dowodem na to jest przytoczony list do Sołtana, ale nie tylko. W korespondencji Zygmunta Krasińskiego pisanej do wielu adresatów z drugiej połowy 1845 roku imię Augustyna pojawia się wielokrotnie, lecz znów nie jako autora fundamentalnych dzieł z filozofii dziejów, tylko pośrednio, za sprawą dokonanej przez romantycznego malarza Ary'ego Scheffera ilustracji fragmentu Wyznań, która poruszyła bardzo szczególnie autora Przedświtu.

\title{
„Piękna Monika, piękna i Ty” czyli czytanie utożsamiające
}

Oto bowiem 3 sierpnia 1845 roku Zygmunt Krasiński pisał z Hagi (tak naprawdę z Paryża) do żony Elizy:

\begin{abstract}
Widziałem wczoraj coś tak pięknego, że muszę Ci o tym kilka słów napisać. Przyjechał tu malarz Ary Scheffer sławny, ten sam, co zrobił Franceskę, zaprowadzono mnie do niego i obaczyłem obraz, który on królowi holenderskiemu sprzedaje - Monikę nad brzegiem morza nawracająca do światła wiary chrześcijańskiej syna swego, jeszcze nie świętego Augustyna! Dopiero wczoraj wróciłem i dowiedziałem się, co jest sztuka malarska, wprzód nie wiedziałem, bo przed żadnym obrazem nigdy mi łzy nie szły do oczu i dreszcz podziwu, uwielbienia, miłości nie przeszywał pleców i piersi ${ }^{15}$.
\end{abstract}

Autor Nie-Boskiej uległ wrażeniu, jakie wywarł na nim obraz Scheffera ${ }^{16}$, choć jak niekiedy przyznawał, raczej nie czerpał z malarstwa szczególnych estetycznych i duchowych korzyści ${ }^{17}$. Krasiński widział jedną - najprawdopodobniej pierwotną

\footnotetext{
${ }^{14}$ Określenia tego używam ze świadomością, że jest to w stosunku do Augustyna rodzaj anachronizmu. Stosuję je oczywiście nie w znaczeniu egzystencjalizmu filozoficznego, a w sensie bardziej potocznym.

${ }^{15}$ Zygmunt Krasiński, Listy do różnych adresatów, ed. Zbigniew Sudolski (Warszawa: Państwowy Instytut Wydawniczy, 1991), vol. 1, 509.

${ }^{16}$ O stosunku Krasińskiego do sztuk plastycznych pisała ostatnio Olga Płaszczewska w artykule „Zygmunt Krasiński wobec sztuk pięknych”, in Zygmunt Krasiński. Światy artystowskie i poetyckie, ed. Agnieszka Markuszewska (Toruń: Wydawnictwo Uniwersytetu Mikołaja Kopernika, 2014), 107-117. Vide Arkadiusz Bagłajewski, „Eschatologia i sztuka”, in idem, Poezja „Trzeciej epoki”. O twórczości Zygmunta Krasińskiego w latach 1836-1843 (Lublin: Wydawnictwo Uniwersytetu Marii Curie-Skłodowskiej, 2009), 70-73.

${ }^{17}$ Warto przy okazji dodać, że dla innych romantyków sztuka, która najpełniej zastępowała nieudolną ekspresję werbalną, była muzyka. Wśród badaczy natomiast dominuje przekonanie o niewielkiej wrażliwości Krasińskiego na sztuki plastyczne, które, być może, warto zweryfikować. Do takiej opinii przyczyniły się pewne wypowiedzi poety. Cf. list Krasińskiego do Konstantego Gaszyńskiego z 14 VI 1845 r., in Zygmunt Krasiński, Listy do Konstantego Gaszyńskiego, ed. Zbigniew Sudolski (Warszawa: PIW, 1971), 106. Cf. Zygmunt Krasiński, Myśli o sztuce, ed. Adam Grzymała-Siedlecki (Lwów: Wydawnictwo E. Wende i Ska, 1912).
} 
- wersję obrazu, który miał potem liczne repliki ${ }^{18}$, a którą z dbałością o szczegóły prezentował w liście do żony:

Syn z ręką złożoną na ręce matki siedzi przy niej, na brzegu morskim. Ona trochę wyżej, cała mórz i powietrza błękitem oblana, na tle tego błękitu beż żadnej chmury, jakby spoczywająca na piersiach Ducha Ś[więte]go. Jej twarz i oczy podniesione w nieskończoność. Wlepiona twarz... i oto, nie żadna przesada, w twarz niczyją inną jedno Boga, bo to znać na jej twarzy wyraźnie i w tym wyrazie nic innego się nie odbija, jedno Bóg - jej lica, jej oczy stały się pod tym pędzlem cudownym zwierciadłem twarzy Bożej, doskonałej piękności ducha! ${ }^{19}$.

Twarz Moniki, która wedle poety przewyższała nawet duchowy ideał madonn Rafaela $^{20}$, zaintrygowała Krasińskiego malarskim wcieleniem idei nieskończoności. „Nic bardziej miłością i zachwytem tchnącego nie widziałem, nie obaczę już - konstatował - i ten obraz przez całe życie stać będzie koło mnie" ${ }^{21}$. Uwaga medytującego nad malowidłem skupia się przede wszystkim na postaci Moniki, choć $\mathrm{w}$ zamyśle malarza matka $\mathrm{z}$ synem przedstawieni są równoznacznie, a mistyczne przeżycie staje się $\mathrm{w}$ równorzędnym stopniu udziałem obojga. Być może Krasiński, który w sposób autoutożsamiajacy i autokreacyjny czytał nie tylko książki, ale i dzieła malarskie, odczuwając "starczą", nieadekwatną do wieku trwogę przed przemijaniem, właśnie w twarzy niemłodej już Moniki ujrzał powinowactwo egzystencjalne. Matka Augustyna mogła też w wyobraźni poety wcielać mit Wiecznej Kobiecości. Jednym z jej kulturowych realizacji jest przywoływana wielokrotnie przez autora Przedświtu Beatrycze Dantego, jako ta, która siłą uczucia wprowadzała ukochanego w świat duchowy, umożliwiając nadprzyrodzone poznanie $^{22}$. Krasiński czytał w każdym razie obraz, włączając siebie i własne doświadczenie w jego interpretację - wznosząc się ponad jego dosłowny, namalowany sens, ujrzał w nim przede wszystkim korelację z prywatnym przeżyciem. Ta swoista egotyczna, upodmiotowiona hermeneutyka, za pomocą której poeta

${ }^{18}$ Vide Gerard Legrand, Sztuka romantyzmu, trans. Ireneusz Waleńczak (Warszawa: Wyd. „Rzeczypospolita”, 2007), 108. Najsłynniejsza, olejna wersja obrazu pochodzi z roku 1846. Jedna z nich sporządzona przez malarza w 1852 stała się własnością Katarzyny z Branickich Potockiej - siostry Elizy. Ary Scheffer, zaprzyjaźniony już wówczas z państwem Krasińskimi, ofiarował akwarelową wersję Moniki i Augustyna szwagierce poety. Przez lata znajdowała się ona w zbiorach Potockich w Krzeszowicach i Krakowie, od 1946 roku stanowi własność Muzeum Narodowego w Warszawie. Vide Chopin. Ikonosfera romantyzmu, ed. Iwona Danielewicz, in cooper. Andrzej Dzięciołowski (Warszawa: Wyd. Muzeum Narodowe w Warszawie, 2010), 323.

${ }^{19}$ Zygmunt Krasiński, Listy do różnych adresatów, vol. 1, 509-510.

${ }^{20}$ Poeta dodawał w tym samym liście: „Błazny, co wyrzekli, że wiek nasz bez ideału. Idealniejszego nic nigdy w przeszłości nie było i Rafael materialistą był przy tym”. Ibidem, 510. O recepcji Rafaela przez romantyków vide Alina Kowalczykowa, „Rafael czyli o stylu romantycznym”, Pamiętnik Literacki, no. 1-2 (1982).

${ }^{21}$ Zygmunt Krasiński, op. cit., 510.

${ }^{22} \mathrm{O}$ micie wiecznej kobiecości w pismach romantyków pisała Maria Cieśla-Korytowska w książce O romantycznym poznaniu (Kraków: Wydawnictwo Literackie, 1997), 99-103. 
szukał nie tyle sensu tekstu, ile samego siebie, jest zakorzenionym w epoce sposobem romantycznej lektury ${ }^{23}$, gdzie ,ja” czytające staje się w tym samym stopniu ważne, co sam tekst i samo staje się tekstem. U Krasińskiego jednak taki sposób poznawania i percypowania sztuki jest wyjątkowy nawet na tle romantycznych subiektywistycznych i egotycznych stylów recepcyjnych, na pewno też nie można opisać go za pomocą kategorii transposition d'art. Można by go natomiast określić mianem hermeneutyki utożsamienia lub hermeneutyki egzystencjalnej, która „w obliczu tekstu Innego prowadzi do samoświadomości interpretującego" ${ }^{24}$ - to taki typ czytania, gdzie szuka się podobieństw, analogii z sytuacją swoją i tekstową, a własne rozważania i doświadczenia narzuca się interpretowanemu dziełu.

Pisząc o Krasińskim jako romantycznym „człowieku czytającym”, Ewa Szczeglacka zwracała uwagę, że czytanie w przypadku autora Przedświtu nie było jednak, jak to się często sądzi, ucieczką od życia, ale miało go „w tym życiu zakorzeniać". Czytając dzieło sztuki - w tym także dzieje Augustyna - romantyczny twórca dookreślał się w rzeczywistości pozaliterackiej ${ }^{25}$. Krasiński, choć życie interpretował w czarnych kolorach, jednocześnie w sposób prawdziwie heroiczny nieustannie ponawiał próby „pokonywania świadomości klęski”, „scalania własnej osoby" i nadawania swemu życiu poczucia sensu, a więc zakorzenienia się w obcej rzeczywistości, za jaką uznawał życie doczesne - „czytając zapuszczał korzenie w świecie i w życiu" ${ }^{\prime 2}$. Pod tym względem - jak przekonująco pisze Anna Kubale - można by widzieć w nim fundatora, a przynajmniej istotnego poprzednika egzystencjalizmu ${ }^{27}$. Autor Przedświtu życie rozumiał bowiem jako ustawiczne, heroiczne pokonywanie tego paradoksu, a lęk towarzyszący ludzkiemu istnieniu, możemy dodać, poeta uśmierzał, obcując z tekstem literackim, malarskim czytanym na sposób konsolacyjny. I być może właśnie w malarskiej ilustracji szczególnego momentu biografii Augustyna próbował odnaleźć antidotum na przeżywane lęki i obawy - czytał ją na sposób autokreacyjny i autoutożsamiający. To z tego zapewne powodu nie Augustyn historiozof i autor Państwa Bożego, lecz Augustyn mistyk i egzystencjalista pokonujący osobiste „akwatofuny” zaintrygował Krasińskiego w sposób szczególny. Romantyczny

${ }^{23} \mathrm{~W}$ podobny sposób Adam Mickiewicz odczytywał w prelekcjach paryskich Nie-Boska komedię, interpretując ją jako dramat mesjanistyczny, w myśli założeń własnej historiozofii i antropologii towianistycznej. Vide Ewa Hoffmann-Piotrowska, Mickiewicz - towiańczyk. Studium myśli (Warszawa: Wydział Polonistyki UW, 2004), 245-248.

${ }^{24}$ Stefan Sawicki, „Medytacja w poznawaniu literatury”, in Medytacja postawa intelektualna, sposób poznania, gatunek dyskursu, ed. Teresa Kostkiewiczowa, Magdalena Saganiak (Warszawa: Wydawnictwo Uniwersytetu Kardynała Stefana Wyszyńskiego, 2010), 97.

${ }^{25}$ Ewa Szczeglacka, Romantyczny homo legens. Zygmunt Krasiński jako czytelnik polskich poetów (Warszawa: Wydział Polonistyki UW, 2003), 11-13.

${ }^{26}$ Ewa Szczeglacka, op. cit., 12.

${ }^{27}$ Cf. Anna Kubale, Dramat bólu istnienia w listach Zygmunta Krasińskiego (Gdańsk: Wydawnictwo Uniwersytetu Gdańskiego, 1997), 154. 
erudyta musiał bowiem wiedzieć, że Ary Scheffer ${ }^{28}$ zilustrował obrazem znaczącą scenę opisaną w dziesiątym fragmencie dziewiątej księgi Wyznań. Choć Bezimienny Poeta nigdzie w listach nie powołuje się na doświadczenie lektury Confessiones, nie jest możliwe, by nie znał ,jednej z najsłynniejszych książek, jakie przechowuje nasza cywilizacja"29.

Krasiński, wyczulony na problematykę śmierci, zapewne wiedział też, że w przywołanej przez malarza księdze Augustyn wspomina ostatnią, poprzedzającą jej rychłą śmierć, rozmowę z matką. Trzydziestoletni filozof i erudyta odnalazł już wówczas drogę prowadząca do supranaturalnej rzeczywistości. Przypomnijmy tylko, że w 386 roku postanowił porzucić intratną i zapewniającą sławę posadę retora, powrócić do Afryki i rozpocząć z garstką oddanych przyjaciół nowe życie. Z początkiem następnego roku przyjął chrzest i z Moniką, przyjaciółmi i synem opuścił Mediolan. Udał się do Ostii, niewielkiego portu pod Rzymem, cierpliwie wyglądając okrętu do Kartaginy, by stamtąd wyruszyć do ojczystej Tagasty $^{30}$. Małe portowe miasto stało się miejscem ostatniego spotkania matki z synem, ostatniej rozmowy, którą w biografii Augustyna zwykło się określać mianem ,widzenia w Ostii” ${ }^{31}$.

Ten moment właśnie zilustrował Ary Scheffer, i z tego obrazu Krasiński wyczytać mógł bliską mu ideę o zbawiającej i odmładzającej sile miłości zakorzenionej w Absolucie. Krasiński, który rozbudował i ufilozoficznił właśnie w latach

${ }^{28}$ Dzieje niezwykłej relacji Krasińskiego z Schefferem przedstawił jeszcze przed wojną Leopold Wellisch w pracy Zygmunt Krasiński i Ary Scheffer. Listy. Z nieznanych rękopisów wydat, wstępem i przypisami opatrzyt L. Wellisch (s.1.: Leopold Wellisch, 1909). Vide Leopold Wellisch, Les Amis romantiques. Ary Scheffer et ses amis polonais (Paryż,1933).

${ }^{29}$ Zygmunt Kubiak, „Od Tagasty do Ostii”, in św. Augustyn, Wyznania, 9.

${ }^{30}$ Podróżni zatrzymali się w małym, ustronnym domu. Po wielu wiekach Zygmunt Kubiak próbował wskrzesić i unaocznić w słowach klimat tamtego miejsca: rzymskiej posiadłości z wewnętrznym podwórzem, z komnatami i pełnymi zieleni krużgankami, gdzie większość czasu spędza się pod gołym niebem. I, jak możemy przypuszczać „taki mały zakątek zieleni oddzielony od gwaru ulicy, taka przestrzeń otwarta - ku górze - a jednocześnie ogarnięta ze wszystkich stron zaciszem domowego życia [...]”. Zygmunt Kubiak, „Pożegnanie w Ostii”, in idem, Pótmrok ludzkiego świata (Kraków: Instytut Wydawniczy „Znak” 2001), 182.

${ }^{31}$ „Gdy zbliżał się dzień - pisał Augustyn - w którym [Monika] miała odejść z tego życia - ów dzień Ty znałeś, a my nie wiedzieliśmy o nim - zdarzyło się, jak myślę, za tajemnym Twoim zrządzeniem, że staliśmy tylko we dwoje oparci o okno, skąd roztaczał się widok na ogród wewnątrz domu, gdzieśmy mieszkali - u ujścia Tybru. Tam właśnie, z dala od thumów, po trudach długiej drogi nabieraliśmy sił do czekającej nas żeglugi. W odosobnieniu rozmawialiśmy jakże błogo. Zapominając o przeszłości, a wyciągając ręce ku temu, co było przed nami, w obliczu prawdy, którą jesteś Ty - wspólnie zastanawialiśmy się nad tym, czym będzie wieczne życie zbawionych, to, czego oko nie widziało ani ucho nie słyszało, i co w serce człowiecze nie wstąpiło". Św. Augustyn, Wyznania, IX $9-10,201$. W całym artykule odwołuję się do ostatniego, poprawionego przez Kubiaka w stosunku do poprzednich, tłumaczenia Confessiones. Inną nieco translację tego fragmentu można znaleźć w cytowanej książce Z. Kubiaka Pótmrok ludzkiego świata, 183-184. Zygmunt Krasiński zapewne, podobnie jak Mickiewicz, czytał Confessiones po łacinie. 
czterdziestych romantyczną teorię miłości, dostrzegał w niej najpełniejszą, jak pisał, asencję ku Stwórcy ${ }^{32}$, „anielską miłość z drugim d u ch e m”"33, widząc w niej nade wszystko terapeutyczne ocalenie. Andrzej Waśko podkreśla ścisły związek u autora Przedświtu romantycznej wizji miłości z refleksją teologiczną ${ }^{34}$ - konkretne, realne uczucie do Delfiny poeta „umistycznił”, „uchrystusowił” ${ }^{35}$, nadając mu soteriologiczny sens. Scenę rozmowy Moniki z synem, przypomnijmy, oglądał poeta zakochany w Delfinie Potockiej, którą wielokrotnie postrzegał jako Beatrycze przeprowadzającą go przez piekło nieznośnego istnienia. Wyobraźnia romantycznego twórcy kazała mu zapewne w scenie przedstawionej na obrazie Scheffera widzieć odbicie własnego emocjonalnego doświadczenia i potwierdzenie budowanej wówczas filozofii miłości, która była stanem umożliwiającym supranaturalne poznanie. W korespondencji z ukochaną, nawiązując do namalowanego potem przez Scheffera (na życzenie poety zresztą), portretu matki Augustyna, pisał jakiś czas później słowa potwierdzające ową utożsamiającą, egzystencjalną lekturę: „Piękna Monika, piękna i Ty”36.

Być może zatem poeta w obrazie romantycznego Rafaela zobaczył ilustrację rozmyślań, które wplótł w list do swojej Beatrycze z maja 1844:

Miłość między duszami - pisał wtedy Krasiński - innego znaczenia mieć nie może i nie ma - wspólna pomoc, asocjacja, by iść ku Bogu. Zwykle dusze na ziemi się asocjują, by iść razem ku ziemskim celom, ku marnostkom znikomym. Licha to miłość wtedy i krótkotrwała zazwyczaj. Ale gdy ich celem Bóg, gdy ich celem coraz wyższe podnoszenie się ku Niemu, gdy podwójnym sercem, jakoby jednym i tym samym, ku pięknu, ku szlachetnemu, ku wszystkim sferom ducha najwznioślejszym wzdychają, wtedy ich miłość wieczna, święta, nieobalana! ${ }^{37}$.

List ten zapewne czytać powinno się w kontekście biograficznym - w korespondencji wiosenno-letniej 1844 roku $^{38}$ ożeniony z Elizą Branicką poeta próbuje intelektualnie wybrnąć z miłosnego trójkąta, pogodzić miłość „obowiązkową”,

${ }^{32}$ Cf. list poety do Delfiny z 18 V 1844 r., w którym poeta pisał: „Miłość między duszami innego znaczenia mieć nie może i nie ma - wspólna pomoc, asocjacja, by iść ku Bogu. Zwykle dusze na ziemi się asocjują, by iść razem ku ziemskim celom, ku marnostkom znikomym. Licha to miłość wtedy i krótkotrwała zazwyczaj. Ale gdy ich celem Bóg, gdy ich celem coraz wyższe podnoszenie się ku Niemu, gdy podwójnym sercem, jakoby jednym i tym samym, ku pięknu, ku szlachetnemu, ku wszystkim sferom ducha najwznioślejszym wzdychają, wtedy ich miłość wieczna, święta, nieobalana!”. Zygmunt Krasiński, Listy do Delfiny Potockiej, ed. Zbigniew Sudolski (Warszawa: Państwowy Instytut Wydawniczy, 1975) vol. II, 444. (dalej cytaty z listów do Potockiej opatruję skrótem LDP).

${ }^{33}$ Vide list do Delfiny Potockiej z 7 VI 1844 r., LDP, vol. II, 465.

${ }^{34}$ Vide Andrzej Waśko, Zygmunt Krasiński. Oblicza poety (Kraków: Wydawnictwo „Arcana”, 2001), 368 i dalej.

35 „Chrystusowa to miłość - pisał do Delfiny Potockiej o ich wzajemnej relacji w liście z 7 VI 1844 r. - miłość to dobra, piękna, mocna [...]”, LDP, vol. II, 464.

${ }^{36}$ List z Nicei z 13 VI 1846 r., LDP, vol. III, 61.

${ }^{37}$ Ibidem, 444.

${ }^{38}$ Cf. list z 22 V 1844 r., ibidem, vol. II, 452-453. 
służącą „marnostkom ziemskim” z idealnym, aspirującym ku Stwórcy uczuciem, które przeżywał w związku z Delfiną. Obraz Scheffera wydaje się pokazywać taką wyższą, spirytualną, „oblewaną” przez Boga miłość, która daje szansę poznania Prawdy w Stwórcy, „bo Bóg - tłumaczył Bezimienny Poeta Potockiej - zarazem jest ws zystkim i sobą s a my m, a my znowu zarazem i s obą s a my mi, a jednak w Nim i przez Niego!" 39 . Ponieważ to kobieta, co pokazywał przywoływany przez Krasińskiego wielokrotnie Dante, w dobijaniu się do Wiecznej Prawdy może pełnić rolę doniosłą, dlatego też, być może, Monika bardziej niż Augustyn na obrazie dziewiętnastowiecznego mistrza zajęła poetę szczególnie ${ }^{40}$. W jej doświadczeniu Krasiński wyczytał wszak prawdę o rewitalizującej i epistemologicznej sile uczucia.

Gdym patrzał na tę twarz matki, syna za sobą ciągnącą do niebios - pisał Elizie - na tę twarz już niemłodą ${ }^{41}$, nie kwitnącą, a tak odmłodniałą przez uczucie, tak rozwitą jak słońce błogości przez zetknięcie się z boskimi promieniami, na tę twarz tak zupełnie duchową, że w niej piękności śladu nie pozostało, tylko rys każdy czoła, oczy, usta, włosy, wszystko, wszystko zdaje się w niebo wstępować, choć stoi na miejscu, płynąć do Boga, choć się nie rusza, cała niebo na sobie nosić w odbiciu, choć nic prócz niej samej nie ma na obrazie ${ }^{42}$.

Krasiński widzi więc Monikę - partnerkę ostyjskiego uniesienia Augustyna - niejako wstępującą w niebo, ale pomija jednocześnie w interpretacji obrazu samego filozofa, w czym znów przejawia się skłonność do autoutożsamiającej lektury. A przecież to, co w przekazie zilustrowanego przez Scheffera fragmentu Wyznań nadzwyczajne, to dialogiczny, wspólnotowy charakter doświadczenia, jakie nad brzegiem morza przydarzyło się matce i synowi. Supranaturalne ekstazy nawiedzające mistyków rodzą się najczęściej w samotności. Dlaczego opisany przez Augustyna fenomen wspólnotowego przeżywania doświadczenia mistycznego Augustyna nie poruszył Krasińskiego? Poeta wszak w tym samym czasie w listach konstruował teorię trzeciego bytu, wyższego istnienia rodzącego się jako skutek przeżyć dwojga dusz splątanych wieczną, nieprzemijająca miłością ${ }^{43}$.

${ }^{39}$ Ibidem, 453.

${ }^{40}$ Powód mógł być jeszcze inny, psychobiograficzny - mianowicie Krasiński wcześnie osierocony przez matkę w sposób szczególny mógł przeżywać pokazaną na obrazie relację matki z synem, tym można by tez tłumaczyć koncentrację poety na postaci Moniki. Interpretacja Augustyna nie jest też daleka od intentio auctoris: Wyznania są bowiem, jak zauważa Zofia Rosińska, mistyczną memorią „pomnikiem pośmiertnym dla matki” vide Z. Rosińska, „Odpryski doświadczenia mistycznego”, in Mickiewicz mistyczny, ed. Andrzej Fabianowski, Ewa Hoffmann-Piotrowska (Warszawa: Wydawnictwa Uniwersytetu Warszawskiego, 2005), 57.

${ }^{41} \mathrm{~W}$ rzeczywistości Monika była wówczas ponad pięćdziesięcioletnią kobietą.

${ }^{42}$ Zygmunt Krasiński, Listy do różnych adresatów, vol. I, 510.

${ }^{43}$ „Wspólnie zastanawialiśmy się nad tym, czym będzie życie zbawionych [...] - wyznaje tymczasem Augustyn - W tęsknocie otwarliśmy nasze serca dla niebiańskiego strumienia płynącego z Twojego zdroju [...]. Doszliśmy w tej rozmowie do rozpoznania [...]. Doszliśmy do naszych dusz i przekroczyliśmy je [...]. Św. Augustyn, Wyznania, IX 10, 201. 
Badacze spuścizny i biografii Augustyna zgodnie podkreślają jego dialogiczne usposobienie, skłonność do filozoficznych dociekań w gronie przyjaciól, a także ideowych adwersarzy - właśnie z dialogu, intelektualnych agonów rodziła się filozofia Augustyna. W podobny sposób filozofował Krasiński, czego dowodem są listy do Cieszkowskiego, Trentowskiego, Libelta, ale i Potockiej.

Co ciekawe, Delfinie, której w owym czasie poeta zwierzał się nieomal ze wszystkiego, nie napomknął o swoim zachwycie dla obrazu Scheffera w żadnym ze znanych listów ${ }^{44}$. Ale zapisana w korespondencji do żony interpretacja dzieła mistrza Scheffera - przykład szczególnej romantycznej ekfrazy - wiele mówi nie tylko o samym obrazie, lecz także (a może przede wszystkim) o sposobie lektury romantycznego twórcy. Krasiński bowiem realizował w sposób szczególny postulat ekspresyjnego czytania. Więcej, używał tekstów jako ilustracji własnych przemyśleń, cytatów potwierdzających subiektywną wizję rzeczywistości. Czytał wybiórczo, poszerzał konteksty interpretacyjne, zadawał pytania, których tekst nie stawiał ${ }^{45}$. Tak, jak się wydaje, czytał także obrazy, a siłę oddziaływania miały szczególnie te, które łączył ze swoimi przeżyciami. Także, gdy w połowie lat czterdziestych zajął się lekturą dzieł Teresy z Ávila, w przeżyciach mistyczki odbijał własne przeżycie, a podmiot jego listów emocje wyrażał słowami zaczerpniętymi z liryków karmelitanki. Własną egzystencję tak mocno stapiał z doświadczeniem Teresy, że listy do Delfiny podpisywał imieniem autorki Twierdzy wewnętrznej ${ }^{46}$ - „Twoja teraz i na wieki święta Teresa” ${ }^{47}$. Słowa mistyczki będące świadectwem żywej i dramatycznej miłości do Boga, jej „namiętność prawdziwie namiętna", fascynująca Krasińskiego furia iberica pomagały poecie przeżyć i wyartykułować uczucie do Potockiej - w jej pismach poeta odnajdywał wzorzec stylistyczny mówienia o zmysłowej miłości. Być może również odmalowana przez Scheffera scena duchowej ekstazy stopionych uczuciem Moniki i Augustyna w podobny sposób pozwalała poecie przeżyć i unaocznić filozofię odnajdywania Boga w „uścisku” dwóch dusz. Krasiński w liście do żony przyznawał się zresztą

${ }^{44}$ W liście z 23 VI 1846 r. wspomina jedynie o tym, że August Cieszkowski pracował nad dziełem Ojcze-nasz pod zawieszoną reprodukcją Moniki i Augustyna pędzla Scheffera. Vide LDP, vol. II, 29 (przypis 9, 31-32). Można jednak podejrzewać, że jakieś listy do Delfiny zaginęły - mianowicie w korespondencji jest np. dość duża, miesięczna nieomal luka między 16 VII a 20 VIII 1845 roku. W tym czasie - 2 sierpnia - Krasiński odwiedził w pracowni Scheffera i zachwycił się św. Moniką.

${ }^{45}$ Parafrazuję tu oczywiście twierdzenia Jonathana Cullera, który w polemice z Umberto Eco, broniąc nadinterpretacyjnej lektury, pisał, o „nadrozumieniu [które - E. H.-P.] polega na rozpatrywaniu pytań, których tekst nie stawia swemu czytelnikowi modelowemu”. Jonathan Culler, „W obronie nadinterpretacji”, in Umberto Eco et al., Interpretacja i nadinterpretacja, ed. Stefan Collini, trans. Tomasz Bieroń (Kraków: Instytut Wydawniczy „Znak”, 2008), 130.

${ }^{46}$ Vide Ewa Hoffmann-Piotrowska, „Zygmunt Krasiński i święta Teresa czyli o pewnym sposobie romantycznej lektury", in eadem, W ustach jest otwór duszy... Szkice o romantykach i mistykach (Warszawa: Wydział Polonistyki UW, 2012), 173-184.

${ }^{47}$ List do Delfiny Potockiej z 8-10 IX 1845 r., LDP, vol. II, 730. 
do ułomności słów, nieadekwatności języka do opisu tej „miłości bez miary”, stanu „pojednania [...] duszy ludzkiej ze wszechmocnością”. „Drugi Rafael” dokonał więc tego, czego język poety dokonać by nie zdołał i „trzeba było 2000 lat po Chrystusie - pisał Krasiński - by tak wgłębić się, w prze paścić s ię, [...] w całą głąb chrześcijańskiego uczucia, w tę otchłań rajskich uniesień i pokoju niebieskiego zarazem" 48 .

\section{Problem otwarty...}

Święty Augustyn jest zatem tylko pozornie nieobecny w dziele Krasińskiego - nikłe literalne odwołania kontrastują z ukrytymi wątkami filozofii Augustyna, które częstokroć zapewne w sposób zapośredniczony, znalazły się w wypowiedziach autora Irydiona. To, jak czytał Augustyna, jak z niego czerpał, jak go „osadzał” w swoim myśleniu o świecie, historii, sobie samym więcej nam pewnie mówią o osobowości intelektualnej Krasińskiego niż o samym filozofie. Stanowią też wyjątkowo interesujący przykład romantycznej hermeneutyki egzystencjalnej.

$\mathrm{Z}$ dostępnych choć nielicznych wzmianek o św. Augustynie w listach Krasińskiego wynika, że poeta widział w nim przede wszystkim zanurzonego w dramatyczną historię egzystencjalistę i szukał w jego doświadczeniu odbicia własnych przeżyć poprzez autoutożasamiającą lekturę. Zbieżności i możliwych inspiracji myślą biskupem Hippony w dziele romantycznego twórcy jest jednak więcej i nie ograniczają się one do narzuconego przez poetę w liście do Sołtana czy przez analizę dzieła Scheffera egzystencjalnego kontekstu. Zapewne wymaga szczególnego, interdyscyplinarnego namysłu historyka literatury i filozofa, by wydobyć na światło dzienne ukryty, pulsujący nurt inspiracji augustiańskich. Zwłaszcza, że lekturę dzieł myśliciela z Hippony uznawali za ważną i inni romantycy. Adam Mickiewicz, którego Krasiński był uważnym czytelnikiem, wyróżniał Augustyna spośród innych autorów. Ślady obcowania z jego myślą odnajdujemy i w Zdaniach $i$ uwagach, prelekcjach paryskich, ale i w listach poety do przyjaciól, w których skwapliwie zachęcał do czytania (po łacinie) Confessiones S-ti Augustini ${ }^{49}$. Kiedy Mickiewicz w liście z grudnia 1833 roku do Hieronima Kajsiewicza i Leonarda Rettla formułował owe wskazówki lekturowe, mniej więcej w tym samym czasie przymierzał się do tłumaczenia Wyznań ${ }^{50}$. Przywiązanie do Augustyna było

${ }^{48}$ Zygmunt Krasiński, LDP, vol. II, 510.

${ }^{49}$ Vide list Adama Mickiewicza do Hieronima Kajsiewicza i Leonarda Rettla z Paryża 16 XII 1833 r., in Adam Mickiewicz, Dzieła, vol. XV (Listy, cz. 2), 253.

${ }^{50} \mathrm{O}$ tym, że Mickiewicz przymierzał się do thumaczenia pism ojców Kościoła, poeta powiadamiał w liście pisanym z Paryża 14 maja 1838 r. do Bohdana i Józefa Zaleskich, vide Adam Mickiewicz, Dzieła. Wydanie Rocznicowe (Warszawa: Spółdzielnia Wydawnicza „Czytelnik”, 2003), vol. XV (Listy, cz. 2), 397. W liście do Bogdana Jańskiego z 9 marca 1838 roku Piotr Semenenko pisze o planach wydawniczych tłumaczenia i przygotowania do druku w kręgu Domku Jańskiego budujących dzieł chrześcijańskich, przy tej okazji wspomina: „Adamowi przypominamy Konfessye św. Augustyna” 
zresztą u autora Pana Tadeusza trwałe, bo jeszcze dziesięć lat później poeta prosił w liście Cezarego Platera, by kupił dla niego ,jaką piękną, małą edycyjkę s. Augustyna Confessiones, „bardzo eleganck[a] na prezent” ${ }^{51}$. I choć podobnie jak w przypadku Krasińskiego bezpośrednich odwołań do filozofa z Hippony nie jest w pismach Mickiewicza zbyt dużo, już nieliczne wzmianki są wystarczającym powodem, by uznać szczególne znaczenie myśli Augustyna dla autora Dziadów.

Mediewalne konteksty twórczości Krasińskiego, podobnie jak Mickiewicza, były oczywiście rozpoznawane i dokumentowane ${ }^{52}$. Do tej pory jednak umykał badaczom problem recepcji w dziele autora Przedświtu myśli św. Augustyna - ważnego przecież współtwórcy europejskiej tradycji filozoficznej, ale jak się wydaje również istotnego inspiratora koncepcji antropologicznych, epistemicznych i na pewno historiozoficznych romantycznych poetów. Nierozpoznana dotychczas recepcja inspiracji św. Augustynem, czy szerzej średniowieczną filozofią, w dziele Krasińskiego ma oczywiście wiele wymiarów: niniejszy artykuł to tylko rekonesans, próba pokazania, że przywoływany przez poetę Augustyn był dla poety ważny przede wszystkim ze względu na prywatne doświadczenie, a to, jak go interpretował (wprost w liście do Sołtana czy pośrednio przez medium dzieła Scheffera) wiele mówi o sposobach romantycznej lektury. Wejście, nawet pobieżne, w pisma poety przekonuje jednak, co jedynie można było tu zasygnalizować, że Krasińskiego warto zobaczyć jako spadkobiercę i apologetę wielkiej tradycji filozoficznej myślenia o historii pełnej znaczeń, w której Bóg mówi do człowieka przez dziejowe wydarzenia, a rolą poety - myśliciela jest odkryć ową mowę Stwórcy. To było jedną z ambicji św. Augustyna i stanowiło epistemiczną tęsknotę autora Traktatu o Trójcy.

Być może rewizji wymaga zatem myślenie o mediewizmie naszych romantyków, poszerzenie kontekstu odniesień do czasów, z którymi tak mocno się oni utożsamiali. Choć Bogusław Dopart potwierdza, że mediewizm w naszym romantyzmie „odegrał znaczącą rolę ideową" ${ }^{53}$, najczęściej jednak jego wpływ sprowadza się do inspiracji estetycznych (gotycyzm, historyzm kolorytu lokalnego,

- jak można mniemać w takim celu, by przynaglić poetę do ich tłumaczenia. Cytat z listu za: Paweł Smolikowski, Historia Zgromadzenia Zmartwychwstania Pańskiego podtug źródeł rękopiśmiennych (Kraków: Nakładem Zgromadzenia Zmartwychwstania Pańskiego, 1893), vol. II, s. 83. Vide Maria Dernałowicz, Ksenia Kostenicz, Kronika życia i twórczości Adama Mickiewicza 1834-1840 (Warszawa: Państwowy Instytut Wydawniczy, 1996), 113.

${ }^{51}$ List Adama Mickiewicza do Cezarego Platera, Paryż 19 I - 5 II 1842 r. (?), in Adam Mickiewicz, Dzieła, vol. XVI (Listy, cz. 3), 22.

${ }^{52}$ Cf. Maria Janion, „Estetyka średniowiecznej Północy”, in eadem, Prace wybrane (Romantyzm i jego media), vol. 4 (Kraków: Universitas, 2001); Karol Sauerland, „Średniowiecze w oczach romantyków niemieckich”, in Archiwum Historii Filozofii i myśli spotecznej, 1967, vol. 13; Zofia Sinko, „Z zagadnień gotycyzmu europejskiego i jego recepcji polskiej”, Pamiętnik Literacki, no. 3, LXIII (1972).

${ }^{53}$ Bogusław Dopart, Romantyzm, vol. 1, ed. Anna Skoczek (Bochnia - Kraków - Warszawa: Wydawnictwo SMS, 2003), 58. 
egzotyzm wieków średnich) ${ }^{54}$, ogólnie ideowych (waloryzacja wartości chrześcijańskich, wieki średnie jako inspirująca, opozycyjna wobec klasycyzmu kontrkultura), a mniej filozoficznych. Odkrywany przez romantyków „cud średniowiecza” wiązał się oczywiście, o czym pisała Maria Janion, z „wielkim dążeniem etycznym, które [romantycy - E.H.-P.] pragnęli zaszczepić własnej epoce" ${ }^{55}$. Choć historycy idei widzą w wiekach średnich podwaliny np. filozofii historii Mickiewicza czy Krasińskiego, trudno nie dostrzec jednak, że w badaniach myśli poetów, poza nielicznymi wyjątkami, brak prac analizujących $w$ ich dziełach recepcje średniowiecznej myśli ${ }^{56}$.

\section{SAINT AUGUSTINE AND ZYGMUNT KRASIŃSKI}

- ON ROMANTIC, SELF-IDENTIFYING READING OF THE PHILOSOPHER OF HIPPO. A RECONNAISSANCE

\section{Sum mary}

The article concerns the reception of St. Augustine in Zygmunt Krasiński's utterances which has not been studied so far. There are very few direct and literal references to the Bishop of Hippo in the writings of this Romantic poet, and yet they are significant and encourage questions about how Krasiński drew from the legacy and biography of the Medieval philosopher and also why he directly referred to him only occasionally even though one can find in the works of the author of Przedświt (Dawnbreaker) a number of elements which overlap with the concepts of the author of Confessions.

On the grounds of the interpretation, made by Krasiński in his letters, of a painting by Ary Scheffer St. Augustine and St. Monica (1846), which moved the poet profoundly, the author of the article presents how subjectively Krasiński read texts, also pictorial works, and hence what content he emphasised in Augustine's literary work. The purpose of this article is to postulate the need for reconsideration of the category of Romantic Medievalism with reference to Polish poets and broadening it to include the context of research on the reception of the principles of Medieval thought in Krasiński, Mickiewicz and other Romantic poets' works.

\footnotetext{
${ }^{54}$ Nowe ujęcie romantycznego mediewizmu vide Dariusz Seweryn, Prehistoria - średniowiecze - romantyzm. Studia i szkice o poezji romantycznej (Warszawa: Wydawnictwo IBL, 2015). Cf. idem, „Romantic medievalism from a new comparative perspective”, Colloquia litteraria, no. 1 (2016): $253-285$.

${ }^{55}$ Maria Janion, „Estetyka średniowiecznej Północy”, in eadem, Prace wybrane (Romantyzm i jego media), 17.

${ }^{56}$ Wyjątek stanowią właściwie prace poświęcone inspiracjom średniowiecznej dominikańskiej szkoły duchowości - zwłaszcza Mistrza Eckharta - w Mickiewiczowskich Zdaniach i uwagach. Problematyką tą zajmowała się m.in. Małgorzata Burta. Vide eadem, „Idea boskości człowieka w Zdaniach i uwagach (Eckhart - Boehme - Silesius - Mickiewicz)", in Mickiewicz mistyczny, ed. Andrzej Fabianowski, Ewa Hoffmann-Piotrowska (Warszawa: Wydawnictwa Uniwersytetu Warszawskiego, 2005), 275-289. Cf. eadem, Reszta prawd. „Zdania i uwagi” Adama Mickiewicza (Warszawa: Wydawnictwo IBL, 2005). O inspiracjach św. Augustynem i Pseudo-Dionizym Areopagitą w gnomach Mickiewicza wspominał także Adam Sikora. Cf. idem, „Nad Zdaniami i uwagami”, in Mickiewicz mistyczny, 266-267.
} 